\title{
PERSEPSI WARTAWAN TERHADAP AKTIVITAS JURNALISTIK INVESTIGASI
}

\author{
Dida Dirgahayu \\ Balai Pengkajian dan Pengembangan Komunikasi dan Informatika Bandung (BPPKI) Bandung \\ J1. Pajajaran No. 88 Bandung-40173, Jabar, Telp.022-6017493,Fax.022-6021740 \\ HP.081573761965. E-mail: dida.bandung@yahoo.co.id \\ Naskah diterima tanggal 2 Maret 2015, direvisi tanggal 12 Mei 2015, disetujui tanggal 22 Juni 2015.

\section{JOURNALIST PERCEPTION OF ACTIVITIES JOURNALISM INVESTIGATION}

\begin{abstract}
Investigative reporting is a journalist working product related to the public interest and contain information that will not be revealed without the efforts of a journalist. Form of original investigative reporting exposing and documenting the various activities subject, previously unknown to the public. The problem in this research is how the perception of journalists on the descriptive with a sample of 20 journalists with the sampling technique is total sample. The results showed reporters normative and practical understanding of journalism and its activities. The reporters have ever been conducting a journalistic investigation. Not all reporters like investigative journalism activities. The journalists motivated conduct investigative journalism because it has the support of companies publishing original work place and feel satisfied with their activities.
\end{abstract}

Keywords: perception, journalists, investigative journalism.

\begin{abstract}
Abstrak
Liputan investigasi merupakan produk kerja jurnalis yang berkaitan dengan kepentingan publik serta mengandung informasi yang tidak akan terungkap tanpa usaha seorang jurnalis. Bentuk pelaporan investigatif orisinal mengungkap dan mendokumentasikan berbagai aktivitas subjek, yang sebelumnya tidak diketahui oleh publik. Masalah dalam penelitian ini adalah bagaimana persepsi wartawan terhadap aktivitas jurnalistik investigasi. Tujuan penelitian adalah untuk mengetahui bagaimana persepsi wartawan terhadap aktivitas jurnalistik investigasi. Metode penelitian adalah deskriptif kuantitatif dengan sampel sebanyak 20 orang wartawan dengan teknik pengambilan sampel adalah total sampel. Hasil penelitian menunjukkan para wartawan memahami secara normatif dan praktis tentang jurnalistik dan aktivitasnya. Para wartawan pernah melakukan kegiatan jurnalistik investigasi. Tidak semua wartawan menyukai kegiatan jurnalistik investigasi. Para wartawan termotivasi melakukan kegiatan jurnalistik investigasi karena mendapat dukungan dari perusahaan penerbitan tempatnya bekerja dan merasa puas dalam melakukan aktivitasnya.
\end{abstract}

Kata kunci: persepsi, wartawan, jurnalistik investigasi. 


\section{PENDAHULUAN}

Penulisan informasi adalah aktivitas penulisan atau penyusunan berita opini dan feature untuk dipublikasikan atau dimuat di media massa tentang peristiwa atau gagasan. Aktivitas tersebut dilaksanakan oleh wartawan dan penulis. Karenanya jurnalistik disebut sebagai "dunia kewartawanan". Menurut UU No.40/1999 tentang Pers (pasal 1 poin 4 ), wartawan adalah orang yang secara teratur melaksanakan kegiatan jurnalistik (Romli, 2007).

Pihak media dan wartawan harus tahan uji, ulet, sabar, dan gigih dalam melawan segala rintangan dan tantangan tersebut. Payung hukum juga sedapat mungkin digunakan untuk melindungi kerja wartawan, antara lain, dengan pemberlakuan UndangUndang Keterbukaan Informasi. Ini bisa menjadi payung hukum untuk menghadapi pihak-pihak yang menghambat akses terhadap informasi.

Jurnalistk investigatisi adalah liputan jurnalistik yang menggunakan teknik-teknik investigasi, karena subjek yang diliput tidak bisa diungkap dengan cara-cara biasa. Ketertutupan itu terjadi karena ada tindak kejahatan/kesalahan/pelanggaran hukum yang dilakukan dan mau disembunyikan dari mata publik.

Dalam melakukan aktivitas liputan jurnalistik investigasi, banyak tantangan dan hambatan yang harus dihadapi, di antaranya kekhawatiran akan adanya gugatan ke pengadilan dengan tuntutan pidana dan gugatan perdata seperti yang pernah dialami oleh Tomy Winata (majalah Tempo). Dalam sistem bisnis media yang makin kapitalistik, ukuran untuk melakukan atau tidak melakukan liputan investigatif sebenarnya sederhana yakni perbandingan antara potensi keuntungan dan kerugian / risiko. Jika potensi kerugian (biaya, dan lain-lain) dan risiko (bermusuhan dengan pihak-pihak yang berkuasa) dianggap lebih besar dari potensi keuntungan yang akan diperoleh (peningkatan tiras, iklan, dan lain-lain) maka tidak ada insentif untuk melakukan liputan investigatif. Ini berlaku untuk media massa mana saja.
Karya jurnalistik investigasi wartawan Indonesia banyak yang tidak didokumentasikan dengan baik. Bukan cuma karya jurnalistik investigasi, tetapi banyak karya jurnalistik tidak terdokumentasikan dengan baik di Indonesia. Berbagai media di Indonesia tampaknya memang tidak memiliki tradisi pendokumentasian yang baik, barangkali karena mereka memandang hal itu bukan prioritas, atau problem dana. Mereka lebih sibuk mencari iklan ketimbang memikirkan soal dokumentasi. Kecuali untuk media semacam Tempo dan Kompas, yang sudah memiliki divisi riset dan kepustakaan yang kuat.

Sejak awal, dasar bagi jurnalisme investigasi adalah kepentingan publik yang memberi legitimasi bagi upaya investigasi. Jika yang diajukan adalah kepentingan pribadi, kelompok, golongan, atau vested interest tertentu, maka jurnalis pada prinsipnya sudah menjadi sekadar alat bagi kepentingan tersebut. Ia tak lagi pantas membawa atribut jurnalis.

Pengetahuan dan keterampilan tinggi dibutuhkan, agar jurnalis bersangkutan tidak melakukan kesalahan teknis dalam peliputan, yang bisa berujung gugatan terhadap medianya. Semangat juang juga dibutuhkan, agar jurnalis tidak mudah menyerah, yang akan berujung pada kegagalan liputan. Liputan investigatif memang menghadapi banyak tantangan (bahkan berpotensi ancaman terhadap keselamatan jurnalis bersangkutan). Sedangkan, dukungan perusahaan media dibutuhkan karena tanpa SDM, dana, waktu, yang disediakan oleh perusahaan, liputan investigatif tidak akan bisa dilakukan. Kalaupun jurnalis nekat "bergerilya," melakukan liputan sendirian, tidak ada jaminan bahwa hasil kerjanya akan dimuat di media bersangkutan. Inilah sebabnya, perlu ada dukungan dari perusahaan

Seorang wartawan tidak lagi cukup hanya bekerja keras. Ia juga harus bekerja cerdas. Seorang wartawan tidak lagi bisa bekerja hanya dengan menyorongkan alat perekam, dan kemudian mengetik apa saja yang terekam dalam alat itu. Jurnalisme 
investigatif bukanlah sekedar fashion. Ia adalah nyawa media saat kini. Berdasarkan realitas inilah penelitian persepsi wartawan terhadap aktivitas junalistik investigasi perlu dilakukan.

Masalah pokok dalam penelitian ini adalah: bagaimana persepsi wartawan terhadap aktivitas jurnalistik investigasi?. Identifikasi masalahnya adalah: (1) Bagaimana pengetahuan wartawan terhadap aktivitas jurnalisme investigasi?; (2) Bagaimana perasaan wartawan terhadap aktivitas jurnalisme investigasi?; Bagaimana kecenderungan perilaku wartawan terhadap aktivitas jurnalisme investigasi.

Tujuan penelitian ini untuk mengetahui persepsi wartawan terhadap aktivitas jurnalisme investigasi. Kegunaan penelitian adalah: (1) Dalam upaya memberikan hasil penelitian dan mendukung kebijakan Komunikasi dan Informatika pada Direktorat Jenderal Informasi dan Komunikasi Publik (IKP) Kementerian Komunikasi dan Informatika RI tentang pembinaan perusahaan penerbitan media massa, perumusan kebijakan berkaitan standardisasi profesi wartawan khususnya pelaksanaan aktivitas jurnalism investigative yang dilakukan oleh para wartawan.

\section{LANDASAN KONSEP}

\section{Persepsi}

Persepsi menurut Gerungan (1996), persepsi dan sikap merupakan kecenderungan bereaksi terhadap objek-objek, di mana kecenderungan bereaksi ini merupakan cara yang khas tergantung dari motivasi, emosi, dan proses kognitifnya. Operasional konsep dari persepsi mengacu kepada tiga komponen sebagai indikator, di mana masing-masing memunyai fungsi yang diarahkan terhadap objek tertentu atau stimulus tertentu.

Indikator persepsi sebagai identifikasi masalah adalah: (1) Komponen kognitif, yaitu pengetahuan pengalaman, pengertian, pemahaman terhadap suatu objek; (2) Komponen afektif, yaitu menyangkut masalah emosional dan sikap seseorang terhadap suatu objek. Objek dirasakan sebagai hal yang menyenangkan, hal disukai atau tidak. Reaksi ini dipengaruhi oleh kepercayaan atau apa yang dipercayai sebagai benar dan berlaku bagi suatu objek; (3) Komponen konatif, berhubungan dengan kecenderungan untuk bereaksi, bertingkah laku dengan cara tertentu, tapi konatif ini tidak meramalkan tingkah laku aktual itu sendiri.

\section{Wartawan}

Wartawan adalah orang-orang yang terlibat dalam pencarian, pengolahan, dan penulisan berita atau opini yang dimuat di media massa, mulai dari pemimpin redaksi hingga koresponden yang terhimpun dalam bagian redaksi. Tidak semua orang yang bekerja di sebuah perusahaan pers (media massa) adalah wartawan (Romli, 2005).

Wartawan adalah seorang profesional, seperti halnya dokter atau pengacara. Ia memiliki keahlian tersendiri yang tidak dimiliki profesi lain, ia juga memunyai tanggung jawab dan kode etik tertentu. Seorang sarjana India, Dr. Laksamana Rao, menyebutkan empat kriteria untuk menyebutkan mutu pekerjaan sebagai profesi, yaitu harus terdapat kebebasan dalam pekerjaan tadi, harus ada panggilan dan keterikatan dengan pekerjaan itu, harus ada keahlian (expertise), dan harus ada tanggung jawab yang terikat pada kode etik pekerjaan (Assegaf, 1985).

Pada umumnya wartawan adalah orang baik, yang mencintai pekerjaannya. Namun kadang-kadang wartawan juga membuat kesalahan, tidak dapat dipercaya, dan tidak dapat menulis dengan baik. Wartawan adalah suatu profesi yang penuh tanggung jawab dan risiko. Karenanya ia harus memiliki idealisme dan ketangguhan. Wartawan bukanlah dunia bagi orang-orang yang ingin bekerja dari jam 9 (Sembilan) pagi hingga jam 5 (lima) sore dan libur pada hari Minggu (Stein,1993).

Charnley dan James M menuturkan, berita adalah laporan tentang suatu peristiwa, opini, kecenderungan, situasi, kondisi, interpretasi yang penting, menarik, masih baru, dan harus secepatnya disampaikan kepada khalayak (Layla, 2000). 


\section{Jurnalistik}

Jurnalistik secara etimologis berasal dari kata journ. Secara sederhana jurnalistik diartikan sebagai kegiatan yang berhubungan dengan pencatatan atau pelaporan setiap hari (Sumadiria,2005). Dalam leksikon komunikasi dirumuskan, jurnalistik adalah pekerjaan mengumpulkan, menulis, menyunting, dan menyebarkan berita dalam karangan untuk surat kabar, majalah, dan media massa lainnya seperti radio dan televisi (Kridalaksana, 1977).

Adinegoro menegaskan, jurnalistik adalah semacam kepandaian mengarang yang pokoknya memberi perkabaran pada masyarakat dengan secepat-cepatnya agar tersiar seluas-luasnya. Secara teknis, jurnalistik adalah kegiatan menyiapkan, mencari, mengumpulkan, mengolah, menyajikan, dan menyebarkan berita melalui media berkala kepada khalayak seluasluasnya dengan secepat-cepatnya (Sumadiria, 2005).

Ridwan mengartikan jurnalistik adalah suatu kepandaian taktis mengumpulkan, menulis, mengedit berita untuk pemberitaan dalam surat kabar, majalah, atau terbitan berkala lainnya. Selain keterampilan praktis, jurnalistik merupakan sebuah seni (Kasman, 2004).

Aktivitas jurnalistik erat kaitanya dengan media massa yang pada hakikatnya adalah merekonstruksikan realitas suatu fakta atau peristiwa yang dipilihnya. Karena sifat dan faktanya, bahwa pekerjaan media massa adalah menceriterakan peristiwa-peristiwa, maka seluruh isi media adalah realitas yang telah dikonstruksikan (constructed reality). Isi media pada hakikatnya adalah hasil rekonstruksi realitas dengan bahasa sebagai perangkat dasarnya, sedangkan bahasa bukan saja alat untuk merepresentasikan realitas, namun juga bisa menentukan relief seperti apa yang akan diciptakan oleh bahasa tentang realitas tersebut (Sobur, 2002).

Dilihat dari segi bentuk dan pengelolaannya, jurnalistik dibagi ke dalam tiga bagian besar, jurnalistik media cetak (news paper and magazine journalism), jurnalistik media elektronik auditif ( radio broadcast jaounalism), dan jurnalistik media audiovisual (television journalism). Produk jurnalistik terbagi menjadi tiga kelompok besar, yaitu: (1) Berita (news), meliputi berita langsung (straight news), berita menyeluruh (comprehensive news), berita mendalam (depth news), pelaporan mendalam (depth reporting), berita penyelidikan (investigative reporting), berita khas bercerita (feature news), dan berita gambar (photo news); (2) Kolompok opini (views), meliputi tajuk rencana, karikatur, pojok, artikel, kolom, esai, dan surat pembaca; (3) Kelompok iklan (advertising ), mencakup berbagai jenis dan sifat iklan. Pemisahan secara tegas berita dan opini merupakan konsekuensi dari normanorma dan etika luhur jurnalistik yang tidak menghendaki berita sebagai fakta objektif, diwarnai atau dibaurkan dengan opini sebagai pandangan yang sifatnya subjektif (Sumadiria, 2005).

\section{Jurnalistik Investigasi}

Liputan investigasi adalah praktik jurnalisme yang menggunakan metode investigasi dalam mencari informasi. Merupakan produk kerja asli jurnalis bersangkutan, bukan hasil investigasi dari sebuah instansi pemerintah atau non pemerintah. Mengandung informasi yang tidak akan terungkap tanpa usaha jurnalis.

Jurnalistik invetigasi juga bisa dikatakan sebagai laporan mendalam bukan hanya sekadar pencarian berita dan ada batasan-batasan yang menuntut tanggung jawab penulis untuk menulis berita secara objektif, tidak memihak, dan mengabdi pada kepentingan umum (Harmonis, 2006).

Bentuk pelaporan investigatif orisinal (original investigative reporting) melibatkan reporter itu sendiri dalam mengungkap dan mendokumentasikan berbagai aktivitas subjek, yang sebelumnya tidak diketahui oleh publik. Jurnalis mungkin menggunakan taktik mirip dengan kerja polisi. Seperti, penggunaan tenaga informan, pemeriksaan catatan/data publik, bahkan dalam situasi tertentu pemantauan aktivitas dengan sembunyi - sembunyi dan penggunaan penyamaran (Arismunandar, 2005). 
Di Indonesia sendiri kurang jelas mulai kapan istilah liputan investigasi mulai menjadi populer. Namun setidaknya ada beberapa majalah yang secara eksplisit pada tahun 1990an menggunakan kata "investigasi" dalam liputan mereka. DwiMingguan Tajuk yang didirikan tahun 1996 memosisikan dirinya sebagai majalah berita, investigasi dan entertainment. Majalah Tempo juga menambahkan satu rubrik "Investigasi" ketika terbit kembali 6 Oktober 1998 (Arismunandar, 2005).

\section{METODE PENELITIAN}

Penelitian ini bersifat deskriptif dengan pendekatan kuantitatif. Menuturkan, menganalisis, menafsirkan, serta mengklasifikasikan realitas sosial tentang persepsi wartawan terhadap aktivitas jurnalistik investigasi. Mengetahui dan menjawab persoalan-persoalan praktis, serta mengevaluasi kondisi-kondisi yang ada pada para wartawan sebagai objek penelitian. Melihat dan menerangkan fenomena dinamika sosial.

Populasi dalam penelitian ini adalah seluruh wartawan yang melakukan tugas kewartawanan yang ada di Kabupaten Kuningan berjumlah 20 responden. Alasan pemilihan lokasi dan populasi karena seluruh wartawan di Kabupaten Kuningan telah mendapatkan pelatihan untuk melakukan aktivitas jurnalistik investigasi. Sampel penelitian ini menggunakan total.

Operasional konsep dalam penelitian ini adalah persepsi, wartawan, jurnalistik, dan jurnalistik investigasi. Persepsi dapat dioperasionalkan ke dalam pengetahuan, kesenangan, dan kecenderungan perilaku. Teknik pengumpulan data dilakukan dengan mempergunakan angket tertutup, wawancara dengan beberapa informan yang memunyai keterkaitan/ mengetahui objek yang diteliti, dokumentasi dan data sekunder yang diperoleh dari data resmi pemerintah maupun swasta yang berhubungan dengan penelitian, serta informasi terbuka dari media cetak, internet, dan media lainnya.

\section{HASIL PENELITIAN DAN PEMBAHASAN}

Dalam penelitian ini persepsi dan sikap merupakan kecenderungan bereaksi terhadap objek-objek, di mana kecenderungan bereaksi ini merupakan cara yang khas tergantung dari motivasi, emosi, dan proses kognitifnya.

Responden dalam penelitian ini berjumlah 20 orang wartawan, terdiri dari 19 orang laki-laki dan hanya 1 orang wartawan wanita.

Profesi wartawan didominasi oleh gender pria, hal ini dimungkinkan karena profesi wartawan merupakan profesi yang tidak mengenal batasan waktu, tempat, mobilitas, bahkan risiko yang mungkin hanya bisa dihadapi oleh kaum laki-laki.

Usia responden yang menjalankan profesi wartawan di Kabupaten Kuningan sangat bervariasi namun dalam penelitian ini yang terbanyak adalah responden yang berusia antara 31-40 tahun sebanyak 10 orang $(50 \%)$.

Sementara itu dilihat dari sisi pendidikan, sebagian besar responden memunyai pendidikan yang cukup tinggi yakni lulus perguruan tinggi. Seperti tergambar pada tabel 1 .

Sebagian besar responden yaitu 14 orang $(70 \%)$ adalah wartawan pada surat kabar harian. 2 responden (10\%) bekerja sebagai wartawan surat kabar mingguan, 2 responden $(10 \%)$ bekerja sebagai wartawan media radio, dan 2 responden (10\%) sebagai wartawan media online.

Semua wartawan telah memeroleh pendidikan tentang kewartawanan. Data ini memperkuat data tentang organisasi profesi yang diikuti yaitu PWI dan ASPEK di mana setiap wartawan yang menjadi anggotanya telah melewati minimal pendidikan dasar kewartawanan. Hasil penelitian menunjukkan sebagian besar responden yaitu 13 orang (65\%) merupakan anggota Persatuan Wartawan Indonesia (PWI) dan 3 orang 
responden (35\%) menjadi anggota Asosiasi Penulis Kuningan.

\section{Pengetahuan tentang Jurnalisme Investigasi}

Para wartawan menguasai pembuatan berita secara langsung sebagai dasar untuk melakukan atau membuat berita liputan seperti liputan investigasi, memahami, dan mengerti tentang jurnalistik. Sebagai wartawan memahami secara normatif dan praktis tentang jurnalistik dan aktivitasnya. Ketidaktahuan tentang jurnalistik lebih kepada aspek normatif seperti definisi dan teori, sementara secara praktis mereka yang tidak memahami pengertian jurnalistik pada kesehariannya melakukan kegiatan jurnalistik.

Walaupun tidak semua wartawan memahami pengertian jurnalistik secara normatif tetapi pada keseharian pekerjaannya responden melakukan kegiatan jurnalistik. Para wartawan memahami pengertian tentang jurnalistik investigatif secara pengertian normatif. Terdapat kesamaan jawaban bahwa tidak semuanya memahami secara normatif pengertian jurnalistik dan pemahaman jurnalistik investigatif.

Para wartawan memahami jurnalistik investigatif secara praktis, hal ini berkaitan bahwa secara normatif responden ada yang tidak mengetahui tentang definisi jurnalistik dan jurnalistik investigasi walaupun dalam kesehariannya secara praktis responden melakukan aktivitas jurnalistik.

Tentang pendidikan kewartawanan yang dimiliki oleh responden, data penelitian menunjukkan bahwa seluruh responden yaitu 20 orang $(100 \%)$ telah memeroleh pendidikan tentang kewartawanan.

Hasil penelitian tentang pendidikan teknis penulisan, sebanyak 20 responden (100\%) menyatakan telah pernah mengikuti pendidikan teknis penulisan. Tentang pekerjaan responden sebagai wartawan, 20 responden $(100 \%)$ menjawab membuat berita langsung.

Terdapat kesesuaian antara perolehan pendidikan kewartawanan secara umum dengan pendidikan teknis secara khusus. Data ini memberikan gambaran bahwa responden memunyai pengetahuan dasar yang baik untuk menjawab pertanyaan tentang aktivitas jurnalistik investigasi dan dipandang mampu melakukan aktivitas tersebut.

Sebelum mendalami data tentang jurnalisme investigasi, responden diberikan pertanyaan dasar tentang pengertian jurnalistik. Sebanyak 12 responden (60\%)

Tabel 1

Pendidikan Formal Responden

\begin{tabular}{llcc}
\hline No & Pendidikan Formal & Jumlah & Persentase \\
\hline 1. & SLTA Sarjana Muda & 2 & 10 \\
2. & Tamat Sana & - & 0 \\
3. & Sarjana (S1) & 15 & 75 \\
4. & S2 & 3 & 15 \\
\hline & Jumlah: & 20 & 100 \\
\hline
\end{tabular}

Sumber : hasil penelitian tahun 2014.

Tabel 2

Masa kerja sebagai wartawan

\begin{tabular}{lrcc}
\hline No & Media Tempat Bekerja & Jumlah & Persentase \\
\hline 1. & $1 \mathrm{~s} / \mathrm{d} 2$ tahun & 8 & 40 \\
2. & $3 \mathrm{~s} / \mathrm{d} 4$ tahun & 1 & 5 \\
3. & $5 \mathrm{~s} / \mathrm{d} 6$ tahun & 4 & 20 \\
4. & $7 \mathrm{~s} / \mathrm{d} 8$ tahun & 4 & 20 \\
5. & $9 \mathrm{~s} / \mathrm{d} 10$ tahun & 3 & 15 \\
\hline & & 20 & 100 \\
\hline
\end{tabular}

Sumber : hasil penelitian tahun 2014 
Tabel 3

Pendidikan Teknis

\begin{tabular}{llcc}
\hline No & Pendidikan teknis & Jumlah & Persentase \\
\hline 1. & Pernah & 20 & 100 \\
2. & Tidak pernah & 0 & 0 \\
\hline & 20 & 100 \\
\hline
\end{tabular}

Sumber : hasil penelitian tahun 2014.

Tabel 4

Menyukai Investigative Reporting

\begin{tabular}{llcc}
\hline No & \multicolumn{1}{c}{$\begin{array}{c}\text { Menyukai Aktivitas Investigative } \\
\text { Reporting }\end{array}$} & Jumlah & Persentase \\
\hline 1. & Menyukai & 18 & 90 \\
2. & Tidak menyukai & 2 & 10 \\
\hline & Tidak melakukan & 20 & 100 \\
\hline
\end{tabular}

Sumber : Hasil penelitian tahun 2014.

menyatakan memahami dan mengerti tentang jurnalistik. Sebanyak 8 responden (40\%) menjawab tidak memahami tentang pengertian jurnalistik.

Semua responden yaitu sebanyak 20 responden $(100 \%)$ menyatakan melakukan kegiatan jurnalistik pada keseharian menjalankan profesinya sebagai wartawan. Sebanyak 13 responden $(65 \%)$ menyatakan memahami pengertian jurnalistik investigatif secara pengertian normatif.

Tentang pemahaman jurnalistik investigatif secara praktis, sebagian besar responden yaitu 19 responden (95\%) menyatakan memahami, dan hanya 1 responden $(5 \%)$ menjawab tidak memahami jurnalistik investigatif secara praktis.

\section{Kesenangan Wartawan terhadap Aktivitas Jurnalisme Investigatif}

Para wartawan menyukai aktivitas jurnalistik investigasi. Kondisi ini sesuai dengan data yang ingin digali dalam penelitian ini. Melakukan kegiatan jurnalistik investigasi karena adanya situasi yang terjadi dan adanya petunjuk awal memunyai bobot yang lebih tinggi dan menggambarkan adanya naluri responden sebagai wartawan.

Seluruh responden atau sebanyak 20 responden (100\%) menyatakan melakukan aktivitas investigative reporting dalam melakukan pekerjaannya sebagai wartawan. Sebanyak 18 Responden (90\%) menjawab mereka menyukai aktivitas jurnalistik investigasi, dan 2 responden (10\%) menyatakan tidak menyukai aktivitas jurnalistik investigasi.

Tetang motif melakukan jurnalistik investigasi, sebanyak 10 responden (50\%) menyatakan karena kondisional tentang peristiwa yang ada, 6 responden (30\%) menjawab karena adanya petunjuk awal, dan 4 responden $(20 \%)$ menyatakan motif melakukan jurnalistik investigasi karena adanya penugasan dari redaksi tempatnya bekerja. Dari 20 responden, sebanyak 13 responden $(65 \%)$ menyatakan bahwa tulisan yang dihasilkannya sebagai wartawan adalah Berita langsung (straight news), 5 responden (25\%) menghasilkan Pelaporan mendalam (depth reporting), 1 responden (5\%) menghasilkan Berita penyelidikan (investigative), dan 1 responden (5\%) menyatakan membuat Berita khas bercerita (feature news) dalam melakukan pekerjaannya sebagai wartawan. Kondisi ini menunjukkan bahwa aktivitas jurnalistik investigasi atau berita penyelidikan masih jarang dilakukan. Hal ini dimungkinkan karena responden dalam kesehariannya hanya sebatas sebagai wartawan biasa dan bukan wartawan investigasi.Tentang cara melakukan 
aktivitas investigative reporting, hasil penelitian menunjukkan, sebanyak 18 responden $(90 \%)$ melakukan sendiri kegiatan peliputan beritanya, 2 responden (10\%) melakukan penyamaran, dan tidak ada responden yang mempergunakan informan dalam melakukan peliputan berita.

\section{Kecenderungan Perilaku Wartawan terhadap Aktivitas Jurnalisme Investigasi}

Kecenderungan perilaku wartawan untuk melakukan jurnalistik investigasi, karena kondisional tentang peristiwa yang ada, dan adanya penugasan dari redaksi tempatnya bekerja.

Para wartawan dalam melakukan jurnalistik investigasi melakukan penyamaran, dan tidak ada responden yang memergunakan informan dalam melakukan peliputan berita. Pada kesehariannya wartawan yang tidak melakukan investigasi jurnalistik, namun melakukan peliputan berita langsung setiap hari, membuat reportase dan berita yang terjadi setiap hari di lingkungannya tanpa melakukan investigasi atau pendalaman tentang peristiwa yang terjadi di lingkungannya yang lebih besar.

Dalam melakukan pekerjaan sebagai wartawan, mereka jarang melakukan kegiatan jurnalistik investigasi, kondisi ini memperkuat jawaban sebelumnya bahwa responden adalah wartawan yang melakukan aktivitasnya sebagai wartawan peliputan berita langsung. Melakukan kegiatan aktivitas investigasi jurnalistik karena adanya penugasan dari redaksi, dan karena kondisional objek liputan.

Jawaban di atas memberikan gambaran bahwa kendatipun responden bukan wartawan yang memunyai spesialisasi investigatif, tetapi dalam melakukan aktivitas jurnalistik investigasi karena adanya realitas kondisional objek liputan dan hanya sedikit persentase yang atas dasar penugasan.

Kondisi dan realitas yang ada di lingkungannya, serta adanya penghargaan dari perusahaan penerbitan menjadi motivasi para wartawan untuk melakukan kegiatan jurnalistik investigasi. Para wartawan menyatakan merasa puas melakukan aktivitas jurnalistik investigasi walaupun dilakukan atas dasar objek realitas dan sedikit yang didasarkan atas arahan dari redaksi di mana responden bekerja. Perusahaan di mana para wartawan bekerja memberikan dorongan atau dukungan kepada para wartawan untuk melakukan kegiatan investigasi jurnalistik. Penghargaan dari perusahaan di mana mereka bekerja terhadap karya tulis yang dibuatnya merupakan dorongan dan dukungan untuk melakukan kegiatan jurnalistik investigasi.

Dalam melakukan aktivitas jurnalistik investigasi, 15 responden (75\%) menyatakan jarang melakukan, dan 5 responden (25\%) menjawab sering melakukan kegiatan jurnalistik investigasi. Jawaban tersebut memperkuat jawaban sebelumnya bahwa responden adalah wartawan yang melakukan aktivitasnya sebagai wartawan peliputan berita langsung. Sebanyak 4 responden (20\%) menyatakan motif melakukan aktivitas investigasi jurnalistik karena adanya penugasan dari redaksi, dan 16 responden $(80 \%)$ menjawab karena kondisional objek liputan.

Tentang dukungan dari perusahaan, bahwa perusahaan memberikan dorongan atau dukungan kepada para wartawan untuk melakukan kegiatan investigasi jurnalistik, atau tidak mendapat dorongan atau dukungan dari perusahaan tempatnya bekerja. Data seperti tergambar pada tabel 5 .

Tabel 5

Dukungan Perusahaan

\begin{tabular}{llcc}
\hline No & \multicolumn{1}{c}{ Dukungan } & Jumlah & Persentase \\
\hline 1. & Memberikan dukungan & 18 & 90 \\
2. & Tidak memberikan dukungan & 2 & 10 \\
\hline & Tidak melakukan & 20 & 100 \\
\hline
\end{tabular}

Sumber : Hasil penelitian tahun 2014. 


\section{PENUTUP}

\section{Simpulan}

Para wartawan memahami secara normatif dan praktis tentang jurnalistik dan aktivitasnya, adapun ketidaktahuan artikulasi tentang jurnalistik lebih kepada aspek normatif seperti definisi dan teori walaupun dalam kesehariannya mereka melakukan kegiatan jurnalistik. Sama halnya dengan pengetahuan tentang jurnalistik, tidak semua wartawan memahami dan mengerti definisi jurnalistik investigasi.

Walaupun secara definisi terdapat responden yang tidak memahami pengertian jurnalistik dan jurnalitik investigasi, para wartawan pernah melakukan kegiatan investigative reporting. Kendatipun pernah melakukan liputan jurnalistik investigasi, tidak semua wartawan menyukai kegiatan jurnalistik investigasi.

Kecenderungan perilaku para wartawan melakukan jurnalistik investigasi sama halnya dengan melakukan liputan rutin berita, yaitu karena adanya kondisi atau realitas yang terjadi adanya petunjuk awal tentang objek berita, selain realitas, para wartawan melakukan kegiatan jurnalistik investigasi karena adanya penugasan dari redaksi.

Pernah melakukan kegiatan jurnalistik investigasi memunyai arti bahwa para wartawan jarang atau tidak setiap saat melakukan kegiatan investigasi terhadap suatu objek berita, wartawan sebagian besar banyak membuat atau menghasilkan karya jurnalistik berupa berita langsung (straight news). Kondisi ini dimungkinkan karena para wartawan dalam kesehariannya hanya sebatas sebagai wartawan biasa dan bukan wartawan investigasi.

Dalam melakukan pekerjaannya, para wartawan sebatas melakukan liputan straight news dan tidak melakukan pendalaman ataupun investigasi, namun para wartawan dapat melakukan liputan jurnalistik investigasi atas dasar realitas peristiwa maupun arahan dari redaksi di mana bekerja.

Para wartawan termotivasi melakukan kegiatan jurnalistik investigasi karena menyatakan mendapat dukungan dari perusahaan penerbitan tempatnya bekerja dan responden merasa puas dalam melakukan aktifitasnya. Selain faktor teknis, dukungan dari perusahaan, para wartawan mendapat penghargaan atau dihargai karya jurnalitik investigasi yang dibuatnya.

\section{Saran}

Wartawan perlu lebih meningkatkan pemahaman dan pengetahuan tentang aktivitas jurnalistik investigasi, menerapkan dalam tugasnya sebagai jurnalis dalam upaya meningkatkan kualitas produk tulisannya dari berita langsung ke laporan investigasi.

Dalam upaya menimbulkan motivasi kerja sebagai jurnalis, perusahaan penerbitan di mana para wartawan bekerja hendaknya memberikan dorongan seperti memberikan kesempatan mengikuti pelatihan jurnalisme investigasi, memberikan penugasan, dan memberikan penghargaan yang lebih terhadap produk jurnalistik investigasi yang dilakukan para wartawan.

Kementerian Komunikasi dan Informatika (Kemkominfo) RI, Dewan Pers, dan perusahaan penerbitan hendaknya membuat satu standar profesi wartawan yang melakukan kegiatan jurnalisme investigasi, karena wartawan investigasi memunyai risiko pekerjaan dan tuntutan kemampuan yang lebih spesifik dibanding wartawan lainnya.

\section{DAFTAR PUSTAKA}

\section{Buku :}

Assegaf, Dja'far. (1985). Jurnalistik Mas Kini Pengantar Kewartawanan. Jakarta: Ghalia Indonesia.

Gerungan,W.A. (1996). Psikologi Sosial. Bandung: Eresio

Kasman, Suf. (2004). Jurnalisme Universal. Jakarta: Teraju.

Kridalaksana, (1977 ). Menulis Berita dan Feature. Bandung: Media Karya.

Layla, S. Mirza. (2000). Politik Dan Radio : Buku Pegangan Bagi Jurnalis Radio. Jakarta: Friedrich Naumann Stiftung. 
Romli dan Asep Syamsul M. (2005). Jurnalistik Terapan. Bandung: Batik Press.

Stein, M.L. (1993). Bagaimana Menjadi Wartawan. Jakarta: PT. Rineka Cipta.

Sobur, Alex. (2002). Analisis Teks Media. Bandung: Remaja Rosda Karya.

Sumadiria, Haris. (2005). Jurnalistik Indonesia. Bandung: Simbiosa Rekatama Media.

\section{Internet :}

Harmonis. (2006). Jurnalisme Inverstigasi dan Mengungkap Korupsi melalui Media.Tersedia dalam: $<$ http:download.portalgaruda.org/article .php?article $=168616 \& v a l=4568 \&$ title $=\mathrm{J}$ urnalistik Investigasi dan Mengungkap Korupsi Melalui Media>, diakses 09 Maret 2014. 